Kinga Baczyk-Rozwadowska

Uniwersytet Mikolaja Kopernika w Toruniu

\title{
ZASADY SŁUSZNOŚCI JAKO INSTRUMENT OCHRONY POSZKODOWANYCH W PRAWIE MEDYCZNYM
}

\section{Uwagi wprowadzające}

Szkody wyrządzone przy leczeniu (tzw. medyczne) stanowią szczególną kategorię w sferze odpowiedzialności odszkodowawczej. Z reguły bowiem, jako szkody na osobie (w postaci uszkodzenia ciała bądź/i rozstroju zdrowia), mają charakter poważny, a niejednokrotnie - nieodwracalny i pociągają za sobą negatywny wpływ na całokształt sytuacji osobistej i majątkowej poszkodowanego. Na lekarzu, zgodnie z poglądem przyjmowanym w piśmiennictwie i doktrynie, spoczywa obowiązek wysokiej (w stosunku do innych profesjonalistów w obrocie) miary staranności w działaniu (art. $355 \S 2$ k.c.). ${ }^{1}$ Pomimo jej dochowania, nawet w najwyższej z możliwych postaci (exactissima diligentia), szkoda niejednokrotnie i tak powstaje, ponieważ nie można jej w żaden sposób zapobiec ani wyeliminować. Szczególnie zatem potrzebne, wręcz pożądane, wydaje się zapewnienie poszkodowanym (pacjentom) daleko idącej ochrony i wprowadzenie odpowiednich mechanizmów prawnych, które pozwalałby na kompensację najpoważniejszych i najdotkliwszych szkód, przy jednoczesnym zachowaniu równowagi podmiotów uczestniczących w specyficznej relacji medycznej.

Przez ponad 40 lat, począwszy od wyroku Sądu Najwyższego z dnia 8 stycznia 1965 r. (II CR 2/65), ${ }^{2}$ istotny i w zasadzie jedyny mechanizm korygujący w tym

\footnotetext{
1 Zob. M. Nesterowicz, Prawo medyczne, Toruń 2013 (wyd. X), s. 84. Zob. także wyrok SN z 7 I 1966 r. (I CR 396/65); OSPiKA 1966, z. 12, poz. 278 z glosą M. Sośniaka oraz wyrok SN z 26 X 2003 r. (III CK 34/02); OSP 2005, z. 4, poz. 54 z glosą E. Bagińskiej.

$2 \quad$ OSPiKA 1967, poz. 220 z glosą A. Szpunara. W wyroku tym, mającym niewątpliwie znaczenie przełomowe, SN przesądził o zastosowaniu szczególnego reżimu odpowiedzialności Skarbu Państwa (art. 417 i n. k.c.) w sferze kompensacji szkód wyrządzonych w związku z leczeniem. Lekarza zatrudnionego w zakładzie państwowej służby zdrowia uznano za funkcjonariusza państwowego, za którego działania odpowiedzialność ponosił Skarb Państwa (szpital) na podstawie art. 417 k.c. (jeżeli działanie lekarza miało charakter zawiniony), a wyjątkowo - art. 419 k.c. (w braku winy, gdy za wynagrodzeniem szkody przemawiały zasady współżycia społecznego). Więcej na ten temat zob. K. Bączyk-Rozwadowska, Odpowiedzialność cywilna za szkody wyrządzone przy leczeniu, Toruń 2013 (wyd. II), s. 61 i n.
} 
zakresie stanowiły zasady współżycia społecznego. Norma słusznościowa zawarta w dawnym art. 419 k.c. miała - na co wskazuje znaczący dorobek orzecznictwa - szerokie zastosowanie przede wszystkim w tzw. procesach medycznych. Nowelizacja kodeksu cywilnego z dnia 17 czerwca 2004 r. $^{3}$ nadała formule odpowiedzialności Państwa (władzy publicznej) całkowicie nowy i odmienny kształt. Pojawia się zatem pytanie o to, jaki wpływ wywarły wspomniane zmiany legislacyjne na zakres ochrony poszkodowanych pacjentów i czy oraz ewentualnie w jakim zakresie zasady słuszności (współżycia społecznego) mogą stanowić instrument ochrony poszkodowanych pacjentów.

Analizę aktualnego stanu prawnego warto byłoby jednak poprzedzić przypomnieniem reguł wypracowanych w piśmiennictwie i judykaturze na gruncie dawnego art. 419 k.c., gdyż w dużej mierze zachowują one aktualność pod rządem art. $417^{2}$ k.c.

\section{Ochrona pacjentów na podstawie dawnego art. 419 k.c.}

Zasadniczym celem regulacji zawartej w art. 419 k.c. było rozszerzenie odpowiedzialności Państwa (państwowego zakładu leczniczego) przewidzianej w art. 417 k.c. na przypadki niezawinionego wyrządzenia szczególnie ciężkich postaci szkód, za które żaden podmiot (ani lekarz, ani zakład leczniczy) nie odpowiadał ze względu na fakt, iż źródło uszczerbków stanowiły przyczyny ogólne, działające względem wszystkich, a przydarzające się losowemu poszkodowanemu (tzw. wypadki medyczne, ryzyka terapeutyczne). Jak podnoszono w piśmiennictwie, za pośrednictwem tego przepisu (uznawanego przez niektórych Autorów za „królewski”) Państwo, czyniąc zadość względom humanitarnym, przyjmowało na siebie rolę dobrego Samarytanina i pozwalało na naprawienie szkód we wszystkich tych przypadkach, w których pozostawienie poszkodowanego bez częściowej choćby rekompensaty budziłoby moralną dezaprobatę. ${ }^{4}$

W praktyce, w razie wyrządzenia szkód w związku z leczeniem, występowała całkowita niemal zgodność stanu faktycznego z dyspozycją art. 419 k.c. i spełnione były podstawowe przesłanki zastosowania tego przepisu (szkoda miała charakter poważny i dotkliwy, pacjent tracił żywiciela lub znajdował się w ciężkim położeniu materialnym, a między niezawinionym działaniem lekarza a szkodą istniał adekwatny związek przyczynowy). Zasadnicze kryterium (wyznacznik) oceny za-

Ustawa z dnia 17 czerwca 2004 r. o zmianie ustawy kodeks cywilny oraz niektórych innych ustaw (Dz.U. z 2004 r. $\mathrm{Nr}$ 164, poz. 1692). Nowe przepisy, które weszły w życie z dniem 1 września 2004 r., dostosowały art. 417 i n. k.c. do regulacji zawartej $w$ art. 77 ust. 1 Konstytucji. oraz 209-210. Por. J. Winiarz, O wynagrodzeniu szkód wyrządzonych przez funkcjonariuszy państwowych, Warszawa 1957, s. 54. Więcej na ten temat zob. K. Bączyk-Rozwadowska, Odpowiedzialność..., op. cit., s. 83 i n. 
sadności żądań pozwu (a zarazem wysokości zasądzanego świadczenia) stanowiły zasady współżycia społecznego.

Konieczność utrzymania wyjątkowego charakteru art. 419 k.c. przy jednoczesnym uwzględnieniu ratio legis normy słusznościowej wymagała wyznaczenia granic jej zastosowania. W judykaturze przyjęto, że - podobnie, jak w zakresie pozostałych płaszczyzn kompensacji - art. 419 k.c. mógł być stosowany w sferze szkód doznanych w związku z leczeniem wtedy, gdy działanie sprawcy (lekarza - funkcjonariusza państwowego) zostało podjęte w interesie ogólnym, nie zaś wyłącznie dla dobra poszkodowanego (nazwa użytej w art. 419 k.c. klauzuli generalnej - zasady współżycia społecznego wydawała się aspekt ten dodatkowo uwydatniać). Nadto, objęcie ochroną z art. 419 k.c. uzasadniał fakt istnienia po stronie pacjenta (poszkodowanego) obowiązku poddania się leczeniu.

W wyroku z dnia 20 sierpnia 1968 r. (II CR 310/68)5 Sąd Najwyższy zaznaczył, że zasady współżycia społecznego z reguły przemawiają za naprawieniem przez Skarb Państwa szkody, jakiej doznała osoba poddana przymusowemu szczepieniu ochronnemu, nawet jeśli uprawniony funkcjonariusz przeprowadził zabieg prawidłowo i zgodnie z zasadami sztuki lekarskiej. W uzasadnieniu wyroku podkreślono, że obowiązek szczepień przeciwko chorobom zakaźnym został wprowadzony nie tylko w interesie jednostek, ale także całego społeczeństwa, co czyniło zasadnym obciążenie wszystkich obywateli skutkami ciężkiego rozstroju zdrowia, które pojawiały się wyjątkowo (losowo) w następstwie prawidłowego podania szczepionki. W ocenie Sądu, przyznanie odszkodowania ,przypadkowemu” poszkodowanemu stanowić miało formę społecznej repartycji szkód wyrządzonych wadliwym, choć niezawinionym leczeniem. ${ }^{6}$

Interes ogólny mógł realizować się także poprzez fakt wzbogacenia wiedzy medycznej. Zastosowanie art. 419 k.c. uznano zatem za uzasadnione w sytuacjach, w których podjęte wobec pacjenta leczenie doprowadziło do wykrycia nowej jednostki chorobowej, dotychczas nieopisanej w fachowej literaturze medycznej. W wyroku z dnia 14 grudnia 1973 r. (II CR 629/73)7 Sąd Najwyższy orzekł, że jeżeli pacjent podczas pobytu w szpitalu i w związku leczeniem podjętym w jego interesie doznał niezawinionego zakażenia rzadką, nieznaną w polskim piśmiennictwie medycznym chorobą (paciorkowcem hemoletycznym), możliwe jest domaganie się

$5 \quad$ OSN 1969, nr 2, poz. 38. W tej sprawie małoletni powód domagał się naprawienia szkody (w postaci ciężkiego paraliżu i porażenia mowy), jakiej doznał w następstwie prawidłowego podania obowiązkowej szczepionki przeciwko ospie.

6 Por. wyrok SN z dnia 22 sierpnia 1968 r. (II CR 318/68); OSP 1969, z. 9, poz. 210 z glosą A. Szpunara. Oba wyroki spotkały się z pełną aprobatą ze strony piśmiennictwa, które za nieuzasadniony uznało pogląd, iż wyłącznie jednostka ponosić ma ujemne skutki działalności Państwa podejmowanej w interesie ogólnym. Tak m.in. A. Szpunar, Odpowiedzialność Skarbu Państwa za funkcjonariuszy, Warszawa 1985, s. 252 oraz M. Sośniak, Glosa do orzeczenia SN z dnia 20 sierpnia 1968 r. (II CR 310/68), OSPiKA 1969, z. 3, s. 133 i n. talu zakażono bakterią paciorkowca hemoletycznego, która doprowadziła do powstania zgorzeli gazowej i poważnego uszczerbku na zdrowiu. 
odszkodowania na podstawie art. 419 k.c., jeżeli w ostatecznym wyniku przebieg leczenia przyczynił się do wzbogacenia wiedzy medycznej. W uzasadnieniu jednocześnie podkreślono, że zastosowane wobec pacjenta leczenie było zarazem działaniem służącym dobru ogólnemu; zdrowie i życie człowieka stanowić bowiem miały - w ocenie Sądu - przedmiot szczególnej ochrony, której zapewnienie leżało w interesie całego społeczeństwa, a nie tylko osoby poddanej leczeniu, zwłaszcza w sytuacji, gdy przebieg terapii mógł wyeliminować powstawanie podobnych szkód w przyszłości. Zapoczątkowana wyrokiem tendencja do łagodzenia rygoryzmu przesłanki (wymogu) działania lekarza w interesie ogólnym znalazła swój wyraz w kolejnych orzeczeniach, w których sądy trafnie przyjmowały, że każde leczenie, nawet podjęte dobrowolnie i za zgodą oraz w interesie chorego służy dobru ogólnemu. ${ }^{8}$

Nadto, pacjent mógł domagać się naprawienia szkody na podstawie art. 419 k.c. w sytuacji, w której powikłania zdrowotne doznane w związku z zastosowaniem określonej, najczęściej nowatorskiej metody leczniczej pociągnęły za sobą całkowite jej zarzucenie. Z zasad współżycia społecznego wypływał bowiem - jak wskazywano w wyrokach - nakaz rozłożenia ryzyka tego rodzaju terapii na całe społeczeństwo i nie obciążania nim konkretnego pacjenta poddanego leczeniu. W wyroku z dnia 14 czerwca 1983 r. (IV CR 75/83)9 Sąd Najwyższy wskazał jednocześnie na doniosłą rolę procesów odszkodowawczych i ich znaczenie dla rozwoju medycyny stwierdzając, że sala sądowa nie jest wprawdzie miejscem, gdzie decyduje się o stosowaniu lub odejściu od określonych metod diagnozy i terapii, jednakże proces w konkretnej sprawie może mieć poważny wpływ na kształtowanie się praktyki i postęp w danej dziedzinie medycyny, pozwalając zapobiec powstaniu określonych szkód w przyszłości.

Pomimo wyjątkowego charakteru normy słusznościowej i zgłaszanego w judykaturze postulatu powoływania się na nią w sposób ostrożny i z zachowaniem niezbędnego umiaru, ${ }^{10}$ zakres zastosowania art. 419 k.c. pozostawał stosunkowo szeroki (obejmując m.in. przypadki omyłkowego, niezawinionego uszkodzenia podczas operacji innego organu niż operowany ${ }^{11}$ ). Judykatura konsekwentnie jednak podtrzymywała zasadę zakładającą, iż brak jest podstaw do naprawienia szkody w sytuacji, gdy rozstrój zdrowia mieści się w granicach ryzyka związanego z zabiegiem,

Zob. np. wyrok SN z dnia 14 czerwca 1983 r. (IV CR 75/83); OSN 1984, z. 1, poz. 13.

OSN 1984, z. 1, poz. 13. W tej sprawie lekarze zastosowali u pacjentów z bólami kręgosłupa zastrzyki hydrocortisonum, co spowodowało trwały i nieodwracalny niedowład dolnej części ciała. Przypadki te zostały szeroko opisane $w$ fachowej literaturze medycznej, doprowadzając do całkowitego zarzucenia tej metody.

10 Tak w szczególności wyrok SN z dnia 18 lutego 1972 r. (I CR 609/71); OSPiKA 1972, z. 10, poz. 183.

11 Zob. wyrok SN z dnia 19 października 1971 r. (II CR 421/71); niepubl. Przypadek omyłkowego uszkodzenia innego organu podczas operacji należało raczej rozpatrywać w kategoriach działania zawinionego (jako nieuwage bądź nieostrożność lekarza) i oceniać na gruncie art. 417 k.c. (w dawnym brzmieniu). Powołany wyrok stanowił przejaw dostrzegalnej od połowy lat 60. XX w. tendencji do zbyt szerokiego (ekstensywnego) stosowania art. 419 k.c. Sąy bowiem, napotykając trudności w ustaleniu winy lekarza, zbyt pochopnie zasądzały odszkodowania na podstawie art. 419 kc., odwołując się do szeroko pojmowanej słuszności, nie zawsze w sposób zgodny z regułami ustalonymi w tym względzie przez judykaturę. Więcej na ten temat zob. K. Bączyk-Rozwadowska, Odpowiedzialność..., op. cit., s. 92. 
a pacjent został o jego istnieniu w sposób odpowiedni poinformowany. W wyrokach trafnie podkreślano, że nie istnieje zasada współżycia społecznego, która usprawiedliwiałaby przypisanie Państwu odpowiedzialności odszkodowawczej w sytuacji, gdy zabieg lekarski nie przyniósł oczekiwanego wyniku, a został przeprowadzony prawidłowo (lege artis), w interesie pacjenta i dla jego dobra oraz z zastosowaniem wszelkich dostępnych lekarzowi metod i środków. ${ }^{12}$

\section{Ochrona pacjentów na podstawie art. $417^{2}$ k.c.}

Zgodnie z poglądem utrwalonym w judykaturze i piśmiennictwie, nowa regulacja zawarta w art. 417 k.c. (a więc, konsekwentnie, art. $417^{2}$ k.c.) odnosi się wyłącznie do sfery imperium. Odmiennie niż w stanie prawnym sprzed nowelizacji z dnia 17 czerwca 2004 r., aktualna formuła odpowiedzialności Państwa dotyczy jedynie przypadków, w których do wyrządzenia szkody dochodzi w związku z wykonywaniem prerogatyw władczych. ${ }^{13}$ Hipotezą art. $417^{2}$ k.c. mogą więc zostać objęte szkody wyrządzone przy leczeniu (tzw. legalne) jedynie wówczas, gdy w działaniu zakładu leczniczego pojawi się element władczego kształtowania pozycji prawnej pacjenta. Sytuacja ta, jak się trafnie podkreśla w doktrynie, może mieć miejsce przede wszystkim w razie poddania pacjenta obowiązkowym szczepieniom ochronnym. ${ }^{14}$ Konsekwentnie w rachubę wchodzić mogą także inne postaci leczenia przymusowego, np. hospitalizacja pacjenta w szpitalu psychiatrycznym ${ }^{15}$ oraz poddanie badaniu bądź leczeniu obowiązkowemu na podstawie ustawy o zwalczaniu zakażeń i chorób zakaźnych. ${ }^{16}$

Skutkiem zmiany przepisów jest więc znaczące (w stosunku do dawnej regulacji zawartej w art. 419 k.c.) zawężenie przedmiotowego zakresu ochrony realizowanej przez normę słusznościową. Zastosowanie przymusu leczenia ma charakter wyjątkowy; aktywność lekarzy i zakładów leczniczych w sferze ochrony zdrowia co do zasady nie przyjmuje charakteru władczego (mieści się w sferze dominium),

12 Por. wyrok z dnia 5 października 2012 r. (I ACa 477/11); LEX nr 1238235, w którym SA w Warszawie zaznaczył, że poza przypadkami szczególnymi, Skarb Państwa nie ponosi odpowiedzialności za skutki (normalne ryzyko) powikłań pooperacyjnych (sprawa dotyczyła błędnie przeprowadzonej operacji prostaty i jąder oraz związanego z zabiegiem zakażenia bakterią coli).

13 M. Safjan, Odpowiedzialność odszkodowawcza władzy publicznej (po 1 września 2004 r.), Warszawa 2004, s. 27; E. Bagińska, Odpowiedzialność odszkodowawcza za wykonywanie władzy publicznej, Warszawa 2006, s. 254 i n. oraz M. Nesterowicz, Glosa do wyroku SN z 13 V 2005 r. (I CK 662/04), OSP 2009, z. 12, poz. 134.

14 Tak M. Nesterowicz, Odpowiedzialność cywilna publicznego zakładu opieki zdrowotnej za wyrządzoną szkodę w świetle kodeksu cywilnego i art. 77 ust. 1 Konstytucji RP, PiM 2004, nr 2, s. 58; tenże, Glosa do wyroku SO w Lublinie z dnia 4 kwietnia 2002 r. (IC 656/99), PiM 2004, nr 3, s. 128. Zob. także M. Safjan, Odpowiedzialność..., op. cit., s. 79-81; J. Kremis, (w:) Kodeks cywilny. Komentarz, red. E. Gniewek, Warszawa 2008 (wyd. III), s. 743 oraz K. Bączyk-Rozwadowska, Odpowiedzialność..., op. cit., s. 198.

15 Zob. art. 21 i n. ustawy z dnia 19 sierpnia 1994 r. o ochronie zdrowia psychicznego (Dz.U. z 1994 r. Nr 111, poz. 535 z późn. zm.)

16 Zob. art. 17 i n. ustawy z dnia 5 grudnia 2008 r. o zapobieganiu oraz zwalczaniu zakażeń i chorób zakaźnych u ludzi (Dz.U. z 2008 r. Nr 234, poz. 1570 - t.j.). Por. M. Nesterowicz, Prawo medyczne, s. 197-198; tenże, Zadośćuczynienie pieniężne za doznaną krzywdę w „procesach lekarskich”, PiP 2005, nr 3, s. 13. 
a poddanie się przez pacjenta jakimkolwiek działaniom leczniczym (diagnozy i terapii) wymaga jego zgody.

W wąskim zakresie zastosowania art. $417^{2}$ k.c. w płaszczyźnie szkód wyrządzonych przy leczeniu aktualność zachowa dawne orzecznictwo wypracowane na gruncie art. 419 k.c. Jak dotychczas brak jest rozstrzygnięć sądowych zapadających w procesach medycznych na podstawie art. $417^{2} \mathrm{kc}$. Wydaje się jednak, że przy znaczącym poparciu ze strony doktryny podtrzymane zostanie stanowisko zajęte przez Sąd Najwyższy we wspomnianym już wyroku z dnia 20 sierpnia 1968 r. (II CR 310/68), dotyczącym obowiązkowych szczepień ochronnych. O tendencji tej świadczy najnowsze orzecznictwo sądów niższych instancji, w tym m.in. wyrok Sądu Apelacyjnego w Poznaniu z dnia 22 stycznia 2013 r. (I ACa 1160/12). ${ }^{17}$ Przyjęto w nim, że zasady współżycia społecznego przemawiają za zasądzeniem odszkodowania w sytuacjach, w których z niewyjaśnionych przez naukę i nikogo niezawinionych przyczyn podanie szczepionki wywołuje u pacjenta poważny rozstrój zdrowia. W ocenie Sądu, bez znaczenia pozostaje to, w czyim interesie - ogólnym czy indywidualnym ustanowiony został obowiązek szczepień (każda jednak postać leczenia przymusowego, w tym profilaktyki zdrowotnej wydaje się być podejmowana dla dobra ogólnego i służyć ostatecznie społeczeństwu jako całości - podkreśl K.B.R.). ${ }^{18}$

Wykazanie $\mathrm{w}$ ewentualnym procesie, że do wyrządzenia szkody doszło w związku z wykonywaniem przez szpital prerogatyw władczych (art. $417^{2}$ k.c.) nie powinno przysparzać trudności. W razie leczenia przymusowego (np. przeprowadzenia obowiązkowych szczepień) zakład leczniczy realizuje przecież obowiązek leczenia (profilaktyki chorobowej) nałożony ustawą przez Państwo, a w stosunku do osoby uchylającej się od tego obowiązku możliwe jest zastosowanie środków przewidzianych w odpowiednich przepisach. ${ }^{19}$ Przydatny, nie tylko w przypadkach szkód poszczepiennych (związanych z podaniem szczepionki), ale i innych wspomnianych już sytuacjach leczenia przymusowego, wydaje się zgłaszany w ostatnich latach $\mathrm{w}$ doktrynie i orzecznictwie pogląd zakładający szerokie rozumienie przesłanki wykonywania władzy publicznej. Przyjmuje się, że pojęcie władzy publicznej nie ogranicza się do wąsko pojętego imperium, lecz obejmuje wszystkie formy wy-

17 LEX nr 1322020. W tej sprawie małoletni poszkodowany domagał się kompensacji szkody doznanej w związku z poddaniem go obowiązkowemu szczepieniu przeciwko gruźlicy.

18 Zob. także wyrok SN z dnia 4 marca 2008 r.; LEX nr 371407, w którym trafnie przyjęto, że uzależnienie odpowiedzialności Państwa od tego, czy działanie funkcjonariusza miało na celu ochronę interesu ogólnego, czy też dobra poszkodowanego, stanowi nieuzasadnione ograniczenie stosowania art. 419 k.c. Nadto, w aktualnym stanie prawnym zmiana terminologii (z zasad współżycia na reguły słuszności) wydaje się dodatkowo uzasadniać odejście od wymogu, by sprawca szkody działał dla dobra ogólnego.

19 W razie uchylania się od obowiązku szczepienia w rachubę wchodzi zastosowanie sankcji przewidzianych ustawą z dnia 17 czerwca 1966 r. o postępowaniu egzekucyjnym w administracji (Dz.U. z 2005 r. Nr 229, poz. 1954, z późn. zm.), tj. grzywny w wysokości do 10,000 zł. Jeżeli egzekucja administracyjna okaże się nieskuteczna, osoba uchylająca się od obowiązku szczepienia podlegać będzie odpowiedzialności karze nagany bądź grzywny od 20 zł do 1,500 zł, przewidzianej w kodeksie wykroczeń (art. 115 § 1 i § 2). Zob. wyrok NSA z dnia 6 kwietnia 2011 r. (II OSK 32/11), w którym przyjęto, że wykonanie obowiązku poddania się szczepieniom ochronnym zabezpieczone jest przymusem administracyjnym oraz odpowiedzialnością regulowaną przepisami kodeksu wykroczeń (podaję za M. Nesterowicz, Prawo medyczne, s. 197). 
konywania zadań publicznych, nawet pozbawionych elementu władczego, ale wpływających na sytuację prawną jednostki; wystarczające jest to, by powód znalazł się w sytuacji prawnego i faktycznego przymusu. ${ }^{20}$

Wejście w życie art. 77 ust. 1 Konstytucji i dokonana w związku z tym nowelizacja kodeksu cywilnego z dnia 17 czerwca 2004 r. wywarła jednocześnie istotny wpływ na rolę zasad współżycia społecznego w procesach odszkodowawczych. Jak dowodzi orzecznictwo, względy humanitarne, do których odwołuje się norma słusznościowa (art. 419 k.c., a następnie - art. $417^{2}$ k.c.), pozwalają na szersze (liberalniejsze) ujmowanie związku przyczynowego i interpretowanie tej przesłanki z większą swobodą (,erozja słusznościowa” związku przyczynowego). Dostrzegalne staje się odchodzenie od wymogu wykazywania normalności następstw zdarzenia sprawczego na rzecz niekwalifikowanego powiązania kauzalnego w postaci conditio sine qua non (tzw. ogólny związek przyczynowy). ${ }^{21} \mathrm{~W}$ wielu wyrokach zapadających od wejścia w życie art. 77 ust. 1 Konstytucji (początkowo na gruncie art. 419 k.c., a następnie - art. $417^{2}$ k.c.) sądy podkreślają, że realizacja postulatu uczynienia zadość zasadom współżycia społecznego pozwala - w szczególnych okolicznościach - poprzestać na wykazaniu łączności przyczynowo-skutkowej pomiędzy zdarzeniem szkodzącym a szkodą, bez konieczności dowodzenia normalności powiązań kauzalnych. W każdym przypadku wymagana jest jednak łączność tego rodzaju, że bez określonego działania (choćby w pełni prawidłowego) nie doszłoby do powstania uszkodzenia ciała, rozstroju zdrowia czy utraty żywiciela. ${ }^{22}$

Sąd Najwyższy po raz pierwszy opowiedział się expressis verbis za dopuszczalnością odejścia od normalności następstw zdarzenia sprawczego na rzecz ogólnego związku przyczynowego w procesach medycznych w wyroku z dnia 4 marca 2008 r. (IV CSK 453/07). ${ }^{23}$ Przyjęto w nim, że dla spełnienia humanitarnego celu realizowanego przez art. 419 k.c. dopuszczalne jest przyznanie pacjentowi odszkodowania w sytuacji, w której relacji kazualnej między zdarzeniami szkodzącymi a doznanym uszczerbkiem na zdrowiu nie da się kwalifikować jako przyczynowo adekwatnej w rozumieniu art. $361 \S 1$ k.c. Jednocześnie Sąd zaznaczył, zgodnie z przyjmowanym wcześniej poglądem, że wymagane dla przypisania odpowiedzialności Państwa niekwalifikowane powiązanie kazualne ma miejsce wtedy, gdy określone zdarzenie

20 M. Safjan, Odpowiedzialność odszkodowawcza władzy publicznej (po 1 września 2004 r.), Warszawa 2004, s. 27 i n. oraz E. Bagińska, Odpowiedzialność odszkodowawcza za wykonywanie władzy publicznej, Warszawa 2006, s. 258 i n. Zob. także wyrok SN z 8 XI 2012 r. (I CSK 163/12); OSP 2014, z. 1, poz. 16 z glosą K. Bączyk- Rozwadowskiej oraz wyrok TK z 23 V 2006 r. (SK 51/05); OTK-A 2006, z. 5, poz. 58 i wskazane tam orzecznictwo.

W literaturze podkreśla się, że tego rodzaju przewartościowanie podstaw stosowania art. $417^{2}$ k.c. (a wcześniej - art. 419 k.c.) spowodowane zostało eliminacją winy funkcjonariusza z zakresu przesłanek odpowiedzialności Państwa. Na ten temat zob. G. Bieniek, Odpowiedzialność Skarbu Państwa za szkody wyrządzone przez funkcjonariuszy po wyroku Trybunału Konstytucyjnego z dnia 4 grudnia 2001, PS 2002, nr 4, s. 3 i n. oraz Z. Radwański, A. Olejniczak, Zobowiązania - część ogólna, Warszawa 2005 (wyd. V), s. 204.

22 Tak m.in. wyrok SN z dnia 11 lutego 2004 r. (I CK 222/03); LEX nr 175945.

23 LEX nr 371407. Sprawa dotyczyła małoletniego pacjenta, okaleczonego w oko odłamkiem petardy; niewykrycie ciała obcego, niemożliwe w stanie rozwoju wiedzy i techniki medycznej w chwili leczenia w Polsce, utrwaliło szkodę i doprowadziło do całkowitej utraty wzroku. 
(causa) powoduje w danych okolicznościach określony skutek, który w zwyczajnym biegu rzeczy nie występuje.

Analiza orzecznictwa wskazuje na to, że stanowisko zajęte w wyroku z dnia 4 marca 2008 r. (IV CSK 453/07) kontynuowane jest także w aktualnym stanie prawnym, na gruncie art. $417^{2}$ k.c., na razie przez sądy niższej instancji. W wyroku z dnia 12 września 2012 r. (I ACa 527/12) 24 $^{24}$ Sąd Apelacyjny w Katowicach stwierdził, że kwestię charakteru relacji kauzalnej, jaka powinna łączyć zdarzenie szkodzące ze szkodą, należy rozpatrywać nie tyle w kontekście problematyki przesłanek odpowiedzialności z art. $417^{2}$ k.c., lecz raczej na bardziej elastycznej płaszczyźnie zasad współżycia społecznego. Wyjątkowo zatem, z uwagi na humanitarne względy normy zawartej w art. $417^{2}$ k.c., możliwe jest przyjęcie odpowiedzialności Państwa na podstawie istnienia niekwalifikowanego powiązania kauzalnego.

Tendencje najnowszego orzecznictwa do stosunkowo szerokiego ujmowania przyczynowości na tle art. $417^{2}$ k.c. rodzą pytanie o to, jak dalece można i należy, w imię humanitaryzmu, łagodzić tę przesłankę, która w procesach medycznych i tak ujmowana jest mniej rygorystycznie (o czym świadczy m.in. dopuszczalność poprzestania na wykazaniu wysokiego stopnia prawdopodobieństwa powiązań kauzalnych, szerokie zastosowanie domniemań faktycznych związku przyczynowego z art. 231 k.p.c. i tzw. dowodu prima facie). Czy np. z samego faktu pobytu w szpitalu (poddania pacjenta przymusowej hospitalizacji na mocy ustawy psychiatrycznej) możliwe będzie wnioskowanie o istnieniu ogólnego związku przyczynowego (według prostego rozumowania: gdyby nie przebywał w szpitalu, nie doszłoby do powstania szkody)? Pogląd ten wydaje się daleko idący i nie uzasadniony nawet w obliczu postulatu zapewnienia daleko idącej ochrony poszkodowanym. Przyjęcie takiego rozwiązania mogłoby bowiem prowadzić do rozwiązań krzywdzących pozwanego i naruszenia równowagi podmiotów uczestniczących w specyficznej, opartej na zaufaniu relacji medycznej.

Nadto, przełamywanie bariery normalności na gruncie art. $417^{2}$ k.c. niewątpliwie postawi przed orzecznictwem konieczność rozstrzygnięcia o tym, czy zabieg ten jest zasadny i dopuszczalny w stanowiących zdecydowaną większość przypadkach wyrządzenia szkód, w których podstawę kompensacji stanowią przepisy ogólne reżimu ex delicto (art. 415 i art. 430 k.c.). ${ }^{25}$ Za przyjęciem takiego rozwiązania wydaje się przemawiać postulat zapewnienia daleko idącej i zarazem jednolitej ochrony poszkodowanym niezależnie od sfery aktywności podmiotu leczniczego (imperium

Oparcie odpowiedzialności za szkody wyrządzone przy leczeniu na ogólnych przepisach reżimu deliktowego uzasadnia się tym, że zakłady lecznicze oraz personel medyczny (lekarze) co do zasady działają w sferze dominium. Na ten temat K. Bączyk-Rozwadowska, Odpowiedzialność..., op. cit., s. 182 i n. Zob. także wyrok SN z dnia 15 maja 2005 r. (I CK 662/04), w którym stwierdzono, że publiczne zakłady opieki zdrowotnej utworzone przez organy administracji nie stają się organami władzy publicznej, ponieważ nie kształtują w drodze przymusu sytuacji prawnej pacjentów. Konsekwentnie, podstawę odpowiedzialności tych podmiotów za wyrządzone pacjentom szkody stanowią przepisy ogólne reżimu ex delicto (podaję za M. Nesterowicz, Prawo medyczne. Komentarze i glosy do orzeczeń sądowych, Warszawa 2012, s. 25 i n.). 
bądź dominium), zwłaszcza że także i w tej - zasadniczej i dominującej nad wąsko stosowanym art. $417^{2}$ k.c. - sferze odpowiedzialności za szkody wyrządzone przy leczeniu dostrzegalna jest w ostatnich latach tendencja do coraz szerszego ujmowania związku przyczynowego, powoływania się na związek pośredni, ${ }^{26}$ przyjmowania faktycznego domniemania przyczynowości. ${ }^{27}$

\section{Uwagi końcowe}

Zasadniczy cel regulacji zawartej w art. 419 k.c. - uzupełnienie ochrony, jaką zapewniała pacjentom generalna formuła art. 417 k.c., został w zasadzie osiągnięty. W doktrynie podnoszono, że norma słusznościowa stanowiła korzystny dla pacjentów mechanizm kompensacji i w dostatecznym stopniu chroniła poszkodowanych, zwłaszcza w zakresie ryzyk terapeutycznych oraz tzw. wypadków medycznych, tj. szkód niezawinionych, doznawanych losowo przez jednostki w następstwie zdarzeń nagłych i nieprzewidzianych, a mających związek z leczeniem. ${ }^{28}$ Rozwiązanie przyjęte w art. 419 k.c. w pewnym stopniu czyniło jednocześnie zadość europejskim i światowym postulatom odchodzenia, w celu zapewnienia pacjentom daleko idącej ochrony (przynajmniej na niektórych płaszczyznach kompensacji, np. wspomnianych wypadków medycznych), od przesłanki winy na rzecz tzw. systemu no fault compensation (Nowa Zelandia, kraje skandynawskie).

Usunięcie tego przepisu z porządku prawnego spotkało się z poważną krytyką ze strony niektórych przedstawicieli piśmiennictwa (zgłaszających postulat przywrócenia zbliżonej regulacji). Podnosi się, że swoistej „luki” w ochronie prawnej, jaka powstała w związku z derogacją tego przepisu, nie wypełnia w dostatecznym stopniu funkcjonujący od dnia 1 stycznia 2012 r. system kompensacji szkód wynikłych ze zdarzeń medycznych. ${ }^{29}$

$\mathrm{Z}$ drugiej jednak strony powstaje pytanie, czy ustawodawca, rezygnując z ochrony poszkodowanych realizowanej za pomocą normy słusznościowej rzeczywiście nie zaoferował żadnej alternatywy. Akcent wydaje się być przesunięty na ochronę praw pacjenta w ogólności (nie istniejącą jeszcze w takim kształcie i zakresie w okresie, w którym uchwalono art. 419 k.c., tj. w dobie tzw. paternalizmu medycznego). Zmianie ulega zatem aksjologia ochrony zapewnianej pacjentom, która aktualnie wydaje się pozostawać szeroka m.in. z uwagi na szeroki zakres zastosowania art. 4 ustawy o prawach pacjenta i Rzeczniku praw pacjenta (pozwalającego na wystąpienie z żądaniem zadośćuczynienia za zawinione naruszenie tych

\footnotetext{
26 Zob. wyrok SA w Warszawie z dnia 29 marca 2011 r. (I ACa 917/10), PiM 2011, nr 4, s. 145 i n.

27 Zob. wyrok SA we Wrocławiu z dnia 28 kwietnia 1998 r. (I ACa 308/98), PiM 2002, nr 12.

28 M. Nesterowicz, M. Wałachowska, Odpowiedzialność za szkody wyrządzone przy leczeniu w związku z nowym pozasądowym systemem kompensacji szkód medycznych, (w:) Kompensacja szkód wynikłych ze zdarzeń medycznych. Problematyka cywilnoprawna i ubezpieczeniowa, red. E. Kowalewski, Toruń 2011, s. 24. 
praw $)^{30}$ oraz powołanie wspomnianego już systemu kompensacji szkód wynikłych ze zdarzeń medycznych.

Nadto, w realiach nowego ustroju społeczno-gospodarczego istotne znaczenie ma ekonomiczny wymiar rozwiązania polegającego na nałożeniu na Państwo (władzę publiczną) obowiązku naprawiania poważnych, lecz niezawinionych (legalnych) szkód wyrządzonych w związku z leczeniem. Pojawia się bowiem pytanie o to, czy i w jakim stopniu fundusze publiczne powinny być przeznaczane na naprawienie szkód doznanych przez pacjentów w nowym systemie opieki zdrowotnej, w którym istnieją rozmaite podmiotowe formy realizacji zadań z zakresu lecznictwa, a funkcjonowanie z.o.z. i innych podmiotów leczniczych poddane jest regułom prawa cywilnego i handlowego. 
EQUITY RULES (BONOS MORES) AS A MECHANISM OF COMPENSATION FOR BODILY INJURY IN MEDICAL MALPRACTICE CASES

For over 40 years Article 419 of the Civil Code constituted an extraordinary mechanism of compensation for injuries incurred by patients in the course of medical treatment. This provision, being a kind of no fault liability of the public hospitals, was favourable for the injured and applied, among all, when the damage resulted from obligatory vaccinacion or other compulsory treatment (justified by social reasons), when the patient was treated with new methods which appeared to be harmful and consequently was abandoned by medicine and when a particular patient's case contributed to the development of medical science.

The situation of the injured patients changed significantly with the derogation of Article 419 of the Civil Code, which took place in 2004. The new Article $417^{2}$ of the Civil Code is narrower in scope and, as a rule, does not cover damages resulting from medical malpractice (dominium). The only exception may be, as the doctrine say, compulsory treatment (vaccinations, treatment of contagious diseases and psychiatric patients), since only then can a doctor (a hospital) exercise the power to act as a public authority (imperium). Up to now the Supreme Court has not decided any case on the ground of the new regulation. The doctrine hopes that the view to compensate patients in the narrower scope will be continued anyway.

Keywords: civil liability, medical malpractice, fault (negligence), compensation, non-pecuniary loss, bonos mores 